\title{
In silico screening of hundred phytocompounds of ten medicinal plants as potential inhibitors of nucleocapsid phosphoprotein of COVID-19: An approach to prevent virus assembly
}

\section{Rajan Rolta}

Shoolini University

Rohitash Yadav

All India Institute of Medical Sciences, Rishikesh

\section{Deeksha Salaria}

Shoolini University

Anuradha Sourirajan

Shoolini University

Kamal Dev ( $\square$ kamaldevbhardwaj1969@gmail.com )

Shoolini University

\section{Research Article}

Keywords: RNA binding domain of nucleocapsid phosphoprotein, COVID-19, Molecular docking, Phytocompounds, antiviral and toxicity, Active site prediction.

Posted Date: May 21st, 2020

DOI: https://doi.org/10.21203/rs.3.rs-30484/v1

License: (c) (i) This work is licensed under a Creative Commons Attribution 4.0 International License. Read Full License

Version of Record: A version of this preprint was published at Journal of Biomolecular Structure and Dynamics on August 27th, 2020. See the published version at https://doi.org/10.1080/07391102.2020.1804457. 


\section{Abstract}

Currently, there is no specific treatment to cure COVID-19. Many medicinal plants have antiviral, antioxidant, antibacterial, antifungal, anticancer, wound healing etc. Therefore, the aim of the current study was to screen for potent inhibitors of N-terminal domain (NTD) of nucleocapsid phosphoproteinof SARS-CoV-2.

The structure of NTD of RNA binding domain of nucleocapsid phosphoprotein of SARS coronavirus 2 was retrieved from the Protein Data Bank (PDB 6VYO)and the structures of 100 different phytocompoundswere retrieved from Pubchem. The receptor protein and ligands were prepared using Schrodinger's Protein Preparation Wizard. Molecular docking was done by using the Schrodinger's maestro 12.0 software. Drug likeness and toxicity of active phytocompounds was predicted by using Swiss adme, admetSAR and protox II online servers.

We have identified three potential active sites (named as A, B, C) on receptor protein for efficient binding of the phytocompounds. We found that, among 100 phytocompounds, emodin, aloe-emodin, anthrarufin, alizarine, and dantron of Rheum emodi showed good binding affinity at all the three active sites of RNA binding domain of nucleocapsid phosphoprotein of COVID-19.The binding energies of emodin, aloeemodin, anthrarufin, alizarine, and dantron were $-8.299,-8.508,-8.456,-8.447$, and $-8.322 \mathrm{Kcal} \mathrm{mol}^{-1}$ respectively (site A), $-7.714,-6.433,-6.354,-6.598$, and $-6.99 \mathrm{Kcal} \mathrm{mol}^{-1}$ respectively (site $B$ ), and -8.299 , $8.508,8.538,8.841$, and $8.322 \mathrm{Kcal} \mathrm{mol}^{-1}$ respectively (site $C$ ). All the active phytocompounds follows the drug likeness properties, non-carcinogenic, and non-toxic. Theses phytocompounds (alone or in combination) could be developed into effective therapy against COVID-19.

\section{Introduction}

During the end of year 2019, a venomous corona disease was emerged from the city of Wuhan, China [1]. In a short span of time, corona has spread all across the globe. This newly emerged viral disease was named as coronavirus disease (COVID-19 and also known as SARS-CoV-2) and World Health Organization (WHO) declared COVID-19 as global health emergency. The COVID-19 is transmitted through person to person and by so far has affected 213 countries across the World. Like other coronaviruses, SARS-CoV-2 has large genome (positive-sense, single-stranded RNA) size of around $30 \mathrm{~kb}$, subdivided into 14 open reading frames (ORFs) [2]. The 5'-ORF 1a/ ORF 1 ab encodes for a polyprotein, which is further processed into 16 non-structural proteins (nsp1-16) by proteolytic cleavage [2]. The 3'- end of the RNA genome encodes for 13 ORFs for four structural proteins, such as the matrix (M), small envelope (E), spike (S) and nucleocapsid phosphoprotein (N), and facilitate entry of SARS-CoV-2entry to human cells through human angiotensin converting enzyme 2 (ACE2) receptor [2]. Both structural and nonstructural proteins ensure virus entry into the cells and its replication inside the host cell and therefore serve as potential as drug targets. The current antiviral drugs developed to treat coronavirus (CoV) infections primarily target S protein, the $3 C$-like (3CL), and papain-like (PLP) proteases $[3,4]$. The mutations in the S-protein could lead to escape of viral target by the drugs [4], whereas antiviral proteases 
could act on off targets and leads to potential side effects. Therefore, it is important to identify novel antiviral targets that could inhibit assembly of the virus particles. Viral nucleocapsid protein $(\mathrm{N})$ is a potential antiviral drug target, serving multiple critical functions during the viral life cycle, including packaging the viral RNA genome $[5,6,7,8]$. The N-protein binds viral RNA genome and results in the formation of ribonucleoprotein (RNP) complex $[7,9]$ The coronavirus $N$ protein has distinct $\mathrm{N}$-terminal RNA-binding domain (NTD), a C-terminal dimerization domain (CTD), and an intrinsically disordered central Ser/Arg (SR)-rich linker $[10,11]$. It is been proposed that NTD is responsible for RNA binding protein and very crucial for transcription and replication of viral RNA [12,13]. Many critical amino acid residues have been identified for RNA binding and virus infectivity in the N-terminal domain (NTD) of coronavirus N proteins [14]. Therefore, NTD of nucleocapsid (N) protein RNA binding domains could be one of the essential drug targets to prevent assembly of virus particles [15].

Currently, there are really no approved drugs for the specific treatment of COVID-19. The COVID-19 is spreading at a much higher rate and the speed of drug discovery is quite slow and lengthy process. In order to speed up the process of drug development against COVID-19, there is an urgent need to take parallel and multidirectional approach to counter the spread of the virus. The approach to develop a vaccine from the scratch is a time taking process and not very good option for stopping an ongoing pandemic. The alternative approach is repurposing existing drugs such as remedesivir and chloroquine against COVID-19 could be a big step forward to curtail the growing threat [16], but not yet approved by US-FDA for the treatment of COVID-19. This approach to new drug discovery against COVID-19 could be further boosted by in silico (hypothesis-based drug designing) approach and repurposing more existing FDA approved drugs $[17,18]$. Moreover, phytocompounds of many medicinal plants have been traditionally used to cure many viral and respiratory diseases [18,19]. Schwarz et al. [20], specifically reported that emodin (major phytocompound of Rheum emodi) act as inhibitor of 3a ion channel of corona virus SARS-CoV and HCoV-OC43 as well as virus release from HCoV-OC4. Ho et al. [21] identified emodin as an effective to block the interaction of the SARS-CoV S protein with the ACE2 and the infection by $\mathrm{S}$ protein-pseudo-typed retrovirus. It was shown that the major phytocompound such as carvacrol and thymol of Thymus serpyllumwere responsible for the antimicrobial, antiviral, antioxidant, antiinflammatory anti-carcinogenic properties [22]. Berberis aristate possess activities such as anti-diabetic, anti-microbial, anti-cancer, antilipidemic, anti-HIV, anti-pyretic, anti-inflammatory, anti-PAF, anti-diarrheal, gynaecological, hepatoprotective, ophthalmic, dermatological and cardiotonic activities [23].Moringa oleifera possess compounds like L-ascorbic acid, oleic acid, 9-octadecenoic acid, phytol, N-(-1methylethyllidene) benzene ethanamine, 3, 4-epoxy-ethanone, 4-hydroxy-4-methyl-2-pentane, 3-ethyl-2,4dimethyl-pentane, 1- hexadecanol, octadecamethyl-cyclononasiloxane, hexadecanoic acid, 3,5-bis (1,1dimethylethyl)-phenol found in plant extract which were responsible for antiviral potential [24].The essential oil of Zanthoxylum armatum contains major phytocompounds such as linalool, limonene, methyl cinnamate and medicinal and possess several biological properties such as antifungal, antibacterial, antiviral, anti-inflammatory, anti-oxidant, cardiovascular and immunomodulatory [25]. The bioactive compounds present in the Piper nigrum were responsible for antimicrobial, antioxidant, anticancer, analgesic, anticonvulsant, neuroprotective, hypoglycemic, hypolipidemic, and anti- 
inflammatory activities [26]. The important bioactive constituents present in Myristica fragrans (nutmeg) include macelignan, carvacrol, myristicin, $\beta$-caryophyllene, $\beta$-pinene, $\alpha$-pinene, $p$-cymene, and eugenol. Various therapeutic or medicinal applications were shown by nutmeg such as antioxidant, antimicrobial, aphrodisiac, anticancer, hepatoprotective, anti-inflammatory, antidepressant, and cardioprotective activity [18]. Accordingly, the dried roots of the Thalictrum foliolosum shows antiplasmodial, antiviral, antibacterial and anti-gastric ulcer activity [27]. Phytocompounds of Allium sativum has been shown to possess in vitro activity against influenza $A$ and $B[28]$, cytomegalovirus [29,30], rhinovirus, HIV, herpes

simplex virus 1 [31], herpes simplex virus 2 Weber et al. [32] viral pneumonia, and rotavirus. Allicin, diallyl trisulfide and ajoene have all been shown to be active [32].

In silico screening of such phytocompounds against specific targets of COVID-19 could provide a continuous feed for in vitro testing and clinical trials. Recently, Kang et al [15] solved the crystal structure of SARS-CoV-2 nucleocapsid protein RNA binding domain and proposed as unique target for developing therapeutics against COVID-19. Therefore, the current study was undertaken to test in silico inhibitory potential of 100 major phytocompounds of ten different medicinal plants including major phytocompounds of $R$. emodi against NTD of nucleocapsid protein RNA binding protein. The phytocompounds identified through in silico studies could become a feeder line for in vitro testing and clinical trials and therefore speed up the process of drug discovery against COVID-19.

\section{Methods}

\subsection{Structure reliability of NTD of nucleocapsid phosphoprotein of SARS coronavirus 2}

The structure of N-terminal domain (NTD, involved in RNA binding) of nucleocapsid phosphoproteinof SARS coronavirus 2 (N proteinPDB ID: 6VYO) was retrieved (http://www.rcsb.org/structure/6VYO). The structure of NTD of N-protein (6VYO) consist of amino acid residues from 50-173 (Figure 2A). The reliability ofRNA binding domain of nucleocapsid phosphoprotein was done usingthe PROCHECK server, which displays Ramachandran plot with distinctive properties of protein such as most favored region, additional allowed regions, generously allowed regions, Disallowed regions, The End residues, Proline, Glycine and total number of residues.

\subsubsection{Preparation of NTD of nucleocapsid phosphoprotein of SARS coronavirus 2 for docking}

The three dimensional structure of RNA binding domain of nucleocapsid phosphoprotein from SARS coronavirus 2 (PDB ID: 6VYO) was prepared using Schrodinger's Protein Preparation Wizard, by rectifying bond orders, addition of hydrogen bonds, making zero-order bonds to metal atoms, make disulphide bonds, making selenomethionine to methionine conversion, fill in lost side chains prime, erase waters from het groups, and generate het states using EpikPh 7 to +-2[33]. Protein hydrogen bonds were optimized to remodel by the overlying hydrogen's and minimized using OPLS3e force field [34]. 


\subsubsection{Receptor Grid Generation and Active Sites Prediction of NTD of nucleocapsid phosphoprotein of SARS coronavirus 2 for docking}

Identification of the potential ligand binding sites or active site residues involved in interaction is a foremost step in docking to discover novel chemical substances [35]. The active site residues provide a pocket containing a variety of hydrogen donors, acceptors, hydrophilic regions and hydrophobic regions [36]. The binding cavity in NTD of nucleocapsid protein was identified using computational tools. Grid was generated using Glide module in Maestro 12.0 Schrodinger suite. The atoms of protein were settledinside using the default parameters of the radii of Vander Waal's scaling factor of $1 \AA$ with partial charge cut-off of $0.25 \AA$ using OPLS3e force field [34].

\subsection{Preparationof Phytocompounds (ligands)}

Hundred major phytocompounds of ten medicinal plants (Rheum emodi, Thymus serpyllum, Cymbopogon citrates, Moringa oleifera, Thalictrum foliolosum, Berberis aristata, Piper nigrum,Allium sativum, Myristica fragrans and Zanthoxylum armatum) were utilized for virtual screening and molecular docking study against NTD of nucleocapsid (N-protein) of COVID-19 target proteins. All the hundred phytocompounds were retrieved from thePubChem Database (https://pubchem.ncbi.nlm.nih.gov/). Ligands were prepared by using the ligand preparation module of molecular modeling package with suitable parameters like optimization, ring conformation, 2D to 3D conversion, and determination of protomers, tautomersand ionization states at $\mathrm{pH}$ 7.0; along with partial atomic charges using OPLS3e force fieldwithroot mean square deviation (RMSD) value of $0.11 \AA$.

\subsection{Molecular Docking}

Molecular docking study of selected 100 phytocompounds of 10 medicinal plants for High throughput virtual screening was performed against the NTD of nucleocapsid N-protein (PDB ID: 6YVO). HTVS with flexible docking was performed on Schrodinger's maestro 12.0 between Ligands and active sites of target protein (6YVO).All the hundred ligands were filtered out by Standard Precision docking (SP) using liganddocking process. Allhundred Ligands having best configuration with highest docking score of virtual screening were sorted by Extra Precision (XP) with Flexible docking.

\subsubsection{Binding free energies calculation using prime MM/GBSA approach}

The binding free energies ofligand and receptor complex were analyzed by prime MM/GBSA (Molecular Mechanics Generalized Born Surface Area) module of Schrodinger suite with the OPLS3e force field. The prime MM GBSA ${ }^{-1}$ approach is based on the docking complex and is used to calculate $\Delta$ Gbind of each ligand using the below mentioned equationand as described earlier $[37,38]$.

$\Delta \mathrm{Gbind}=\Delta \mathrm{EMM}+\Delta \mathrm{GSolv}+\Delta \mathrm{GSA}$

Where, $\triangle \mathrm{EMM}$ is the difference in the minimized energiesbetween the 6VYO-ligand complex and the sum of the energies of the unliganded6VYO and inhibitor. $\triangle \mathrm{GSOlv}$ isthe difference in the GBSA solvation 
energy of $6 \mathrm{VYO}$ inhibitor complex and sum of the solvation energies for the free $6 \mathrm{VYO}$ receptor and inhibitor complex and $\triangle G S A$ is the difference in surface area energies for the complex and sum of the surface area energies for the unliganded $6 \mathrm{VYO}$ receptor and inhibitor. MM GBSA ${ }^{-1}$ approach is used as a rescoring function to prioritize the lead inhibitors. The binding free energies obtained from MM GBSA ${ }^{1}$ calculations were considered along with docking score to optimize the identified drug molecules.

\subsection{ADMET and toxicity prediction of active phytocompounds}

Absorption, distribution, metabolism, excretion, and toxicity (ADMET) screening was done to determine the absorption, toxicity, and drug-likeness properties of ligands. The 3D structures of phytocompounds (aloe-emodin, anthrarufin, alizarine, dantron and emodin) were saved in .smiles format and drug were uploaded on SWISSADME (Molecular Modeling Group of the SIB (Swiss Institute of Bioinformatics), Lausanne, Switzerland), admetSAR (Laboratory of Molecular Modeling and Design, Shanghai, China), and PROTOX webservers (Charite University of Medicine, Institute for Physiology, Structural Bioinformatics Group, Berlin, Germany) for ADMET screening. SwissADME is a web tool used for the prediction of ADME and pharmacokinetic properties of a molecule. The predicted result consists of lipophilicity, water solubility, physicochemical properties, pharmacokinetics, drug-likeness, medicinal chemistry, and Brain or Intestinal Estimated permeation method (blood-brain barrier and PGP \pm prediction). admetSAR provides ADMET profiles for query molecules and can predict about fifty ADMET properties. Toxicity classes are as follows: (i) Category I contains compounds with LD50 values $\leq 50 \mathrm{mg}$ $\mathrm{kg}^{-1}$, (ii) Category II contains compounds with LD50 values $>50 \mathrm{mg} \mathrm{kg}^{-1}$ but $500 \mathrm{mg} \mathrm{kg}^{-1}$ but $5000 \mathrm{mg} \mathrm{kg}^{-}$ ${ }^{1}$ (Cheng et al., 2012; Yang et al., 2019). PROTOX is a Rodent oral toxicity server predicting LD $_{50}$ value and toxicity class of query molecule. The toxicity classes are as follows: (Class 1: fatal if swallowed (LD50 $\leq 5)$, Class 2: fatal if swallowed (55000) [39].

\section{Results}

\subsection{Protein structure reliability by Ramachandran Plot}

The scheme for the current study has been summarized in Figure. 1. The secondary structure of NTD (amino acid Ala 50 to Ala 173), theRNA binding domain of nucleocapsid phosphoprotein of SARS coronavirus 2 (6VYO) is shown in Figure $2 \mathrm{~A}$ and secondary structure topology is shown in Figure $2 \mathrm{~B}$. The PROCHECR server presents Ramachandran plot displaying allowed and disallowed regions with regardtobackbonedihedralsof proteinresidues. More than $90 \%$ score of the most favored regions ensures that model has good quality. RNA binding domain of nucleocapsid phosphoprotein of SARS coronavirus 2 (6VYO) proteinshowed $92.5 \%$ of amino acid residues in most allowed regions (Table 1 and Figure $2 \mathrm{C}$ ).

\subsubsection{Preparation of NTD, the RNA binding domain of nucleocapsid phosphoprotein of SARS coronavirus 2 (6VYO)}


The three dimensionalhomo-tetrameric structure of RNA binding domain of nucleocapsid phosphoprotein of SARS coronavirus 2 (PDB ID: 6VYO) was retrieved from RCSB PDB (http://www.rscb.org/pdb) in .sdf format. The protein structure was prepared by correcting bond orders, addition of hydrogen bonds, creating zero-order bonds to metal atoms, creating disulphide bonds, creating selenomethionine to methionine conversion, fill in the missing side chains prime, deleting waters from het groups, and generate het states using EpikPh 7 to +-2 by using Schrodinger's Protein Preparation Wizard (3A-D).

\subsubsection{Receptor Grid Generation and Active Site Prediction}

To predict the active site of RNA binding domain of nucleocapsid phosphoprotein from SARS coronavirus 2 (PDB ID: 6VYO), protein grid was generated by using glid module in maestro 12.0 schrodinger suit. In RNA binding domain of nucleocapsid phosphoprotein from SARS coronavirus 2 (PDB ID: 6VYO) protein, we found three different active sites, namely $A, B$ and $C$ with $D$ score 1.039, 0.99 and 1.045 respectively. The dimensions of the grid box and receptor setup were $x=80 \AA, y=80 \AA, z=80 \AA$ and $x=32 \AA, y=32 \AA$, $z=32 \AA$ respectively with a grid space of $1 \AA$ for all the three binding sites. Active site $A$ was predicted between chain $A$ and $B$. The chain $A$ contributes 26amino acid and chain $B$ contributes 21 amino acids. TheActive site $B$ was predicted between chain $A$ (25 amino acids) and chain $B$ (26 amino acids). Active site $C$ was predicted between chain $C$ and $D$ with 15 and 21 amino acids respectively (Table 2 and Figure 3 A-D). This is important to mention that Thr 76, Ser 78, Ser 105, Thr 166 which are potential phosphorylation sites are involved in formation of active sites $A, B$ and $C$ (Table 2).

\subsection{Ligand preparation}

Hundred major phytocompounds of ten selected medicinal plants(Rheum emodi, Thymus serpyllum, Cymbopogon citrates, Moringa oleifera, Thalictrum foliolosum, Berberis aristata, Piper nigrum, Allium sativum, Myristica fragrans and Zanthoxylum armatum) were used for the docking studies. The 3dimensional structures of all the phytocompounds were obtained from pubchem (www.pubchem.com) in .sdf format. The .sdf file of phytocompounds was converted into PDB format by using the tool Open Babel. Table-3 summarizes the names of the medicinal plants, pharmacological properties and major phytocompounds.Phytocompounds are numbered as 1-100.

\subsection{Molecular Docking analysis of RNA binding domain of nucleocapsid phosphoprotein from SARS coronavirus 2 (PDB ID: 6VYO) target protein and phytocompounds}

Molecular docking of all the 100 phytocompounds with three binding sites (A, B and C) of RNA binding domain of nucleocapsid phosphoprotein from SARS coronavirus 2 (PDB ID: 6VYO)protein was done by using Schrodinger's Software. Active phytocompounds were analyzed by scoring function and binding free energies MM GBSA ${ }^{-1}$. Out of the hundred phytocompounds, only five phytocompounds showed the best interactions with all three-binding site of RNA binding domain of nucleocapsid phosphoprotein from SARS coronavirus 2 (PDB ID: 6VYO) protein (Table 4- 6 and figure 5-10). Molecular structures of five best phytocompounds is shown in figure 4 . The remaining 95 phytocompounds did not show efficient binding (data not shown). 


\subsubsection{Molecular Docking of phytocompounds with active site $A$}

Active site $A$ was predicted between chain $A$ and Chain $B$ with $D$ score 1.039. Among all the selected phytocompounds, only aloe-emodin, anthrarufin, alizarine, dantron and emodin showed the best interaction with docking score $-8.508,-8.456,-8.441,-8.322$ and $-8.299 \mathrm{Kcal} \mathrm{mol}^{-1}$ respectively. Prime MM $\mathrm{GBSA}^{-1}\left(\mathrm{Kcal} \mathrm{mol}^{-1}\right)$, hydrogen bonding and interactive amino acidsare shown in Table 4, Figure 5 and 6.Apart from hydrophobic interactions, $H$-bonds were also detected. Ser 78 of chain $B$, which has been predicted as phosphorylation site showed interaction with all the five phytocompounds.

\subsubsection{Molecular Docking of phytocompounds with active site B}

Active site $B$ was predicted between chain $A$ and chain With $D$ score 0.99. Among all the selected phytocompounds, only emodin, dantron, alizarine, aloe-emodin and anthrarufin showed the best interaction with docking score -7.714, -6.99, -6.598, -6.433 and $-6.354 \mathrm{Kcal} \mathrm{mol}^{-1}$ respectively. Prime MM $\mathrm{GBSA}^{-1}\left(\mathrm{Kcal} \mathrm{mol}^{-1}\right)$, hydrogen bonding and interactive amino acid is shown in Table 5, figure 7 and 8. Both hydrophobic and H-bond interactions were observed. Ser 78 of Chain A and Ser 105 of chain B, the potential phosphorylation residues were also involved in hydrophobic interaction. Exceptionally, Ser 78 of chain A also showed H-bond formation with Aloe-emodin.

\subsubsection{Molecular Docking of phytocompounds with active site $C$}

Active site $C$ was predicted between chain $A$ and chain $d$ with $D$ score 1.045. Among all the selected phytocompounds, anthrarufin, aloe-emodin, alizarine, dantron and emodin showed the best interaction with docking score $-8.538,-8.508,-8.841,-8.322$ and $-8.299 \mathrm{Kcal} \mathrm{mol}^{-1}$ respectively. Prime $\mathrm{MM} \mathrm{GBSA}^{-1}$ $\left(\mathrm{Kcal} \mathrm{mol}^{-1}\right)$, hydrogen bonding and interactive amino acid is shown in Table 6, figure 9 and 10. Hydrophobic interactions and $H$-bonds were detected all the phytocompounds. Ser 78 of chain $D$, the potential phosphorylation residue was also involved in hydrophobic interaction.

\subsection{ADMET prediction and toxicity analysis of active phytocompounds}

The ADME properties predicted by SwissADME of selected phytocompounds are summarized in Table 7 .

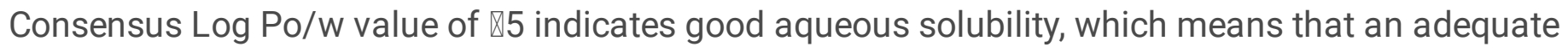
amount of drug can reach the target and can be maintained inside the body through oral administration. All the five phytocompounds have consensus Log Po/w value of $<5$ (Table 7). TPSA indicates a compound ability to permeate into cells. A TPSA value of $<140 \AA 2$ is required for good permeation of compound into the cell membrane and value $<90 \AA 2$ is required to permeate through blood-brain barrier. All the selected phytocompounds have TPSA value $<90 \AA 2$, indicating good permeability of selected phytocompounds through blood-brain barrier. Lipinski's rule of five helps to determine drug-likeness of 
the phytocompounds; an orally active drug should not violate the rule. Both ligands showed 0 violations for Lipinski's rule of five.

Toxicity predicted by PROTOX-II and admetSAR is summarized in Table 8. Data in Table shows that all the selected phytocompounds are non-carcinogenic and non-cytotoxic in nature and are safe to administer. However, $L_{50}$ value of emodin and artemisinin calculated from Protox II was higher than that of all other phytocompounds and chloroquine, indicating that these natural phytocompounds are safer than that of chemically synthesized chloroquine.

\section{Discussion}

Molecular docking studies explored the interaction of 100 major phytocompounds of ten selected medicinal plants(Rheum emodi, Thymus serpyllum, Cymbopogon citrates, Moringa oleifera, Thalictrum foliolosum, Berberis aristata, Piper nigrum, Allium sativum, Myristica fragrans and Zanthoxylum armatum) for interaction with RNA binding domain (NTD) of nucleocapsid phosphoprotein of SARS coronavirus 2.

The molecular docking study showed that out to 100 different phytocompounds, five phytocompounds such as emodin, anthrarufin, alizarine, aloe- emodin and dantron of Rheum emodishowed efficientbinding affinity and pharmacokinetic properties with NTD of RNA binding domain of nucleocapsid phosphoprotein of SARS coronavirus 2 . It is very interesting to note that all the all the five phytocompounds (emodin, aloe-emodin, anthrarufin, alizarine, and dantron) of $R$. emodi bind at three different active sites. Thebinding energies of emodin, aloe-emodin, anthrarufin, alizarine, and dantron was $-8.299,-8.508,-8.456,-8.441$, and $-8.322 \mathrm{Kcal} \mathrm{mol}^{-1}$ respectively (site $\mathrm{A}$ ), -7.714, -6.433, -6.354, -6.598, and $-6.99 \mathrm{Kcal} \mathrm{mol}^{-1}$ respectively (site $B$ ), and $-8.299,8.508,8.538,8.841$, and $8.322 \mathrm{Kcal} \mathrm{mol}^{-1}$ respectively (site $C$ ). Similar to our study, Kumar et al [45] reported the binding affinities of Nelfinavir, Rhein, Withanolide D, Withaferin A, Enoxacin, and Aloe-emodin as -8.4, -8.1, -7.8, -7.7, -7.4, and -7.4 $\mathrm{Kcal}^{\mathrm{mol}^{-1}}$ respectively against main protease (6LU7) of COVID 19.Latha and Pandit [46] reported the binding affinity of phytocompounds derived from Silybum marianum (Silybin), Withania somnifera (Withaferin A), Tinospora cordifolia (Cordioside) and Aloe barbadensis (Catechin and Quercetin) with SARS-CoV-2 target. The binding energies of phytocompounds was more than the widely used hydroxychloroquine and other repurposed drugs used for treatment of COVID-19 infection. Tatara and Kemal [47] reported the binding affinity of nafamostat, rapamycin, saracatinib, Imatinib and Camostat with binding energy -10.24, $-9.28,-9.66,-9.23$ and 9.07 respectively with N-Terminal Domain of SARS-CoV-2 Nucleocapsid. Ubani et al. [48] reported best binding affinity of scopodulcic acid and 249 Dammarenolic acid with the Spike glycoprotein (6VSB) and the Mpro 250 (6FLU7) respectively. The in-silico studies were supported by the fact that Schwarz,et al. [20] reported emodin as inhibitor of 3a ion channel of corona virus SARS-CoV and $\mathrm{HCoV}-\mathrm{OC} 43$ as well as virus release from HCoV-OC43. In another study, Ho et al. [21] identified emodin as an effective to block the interaction of the SARS-CoV S protein with the ACE2 and the infection by $S$ protein-pseudo-typed retrovirus. 
Similar to our study, Ahmed and Shohael [49], reported that the chrysophanol, aloe-emodin, rhein and emodin fulfill all the criteria of Lipinski's rule of five and ADME/T. Nucleocapsid N protein of SARS coronavirus 2 has been predicted to contain many phosphorylation sites at Serine, Threonine and Tyrosine residues [50]. In our study, we found that some of the potential Serine and Threonine residues contribute for the formation of active site A, B and C. Serine at position 78, 79 and 105 also showed interaction with all the five phytocompounds of $R$. emodi. Involvement of potential phosphorylation residues in interaction with phytocompounds could further ensure that NTD of Nucleocapsid N protein of SARS coronavirus 2 render inactive and prevents the assembly of the virus and hence stop the infection.

\section{Conclusion}

Hundred phytocompounds of ten medicinal plants were screened on the bases of binding energy against NTD of Nucleocapsid protein of COVID-19 target. Among all the 100 phytocompounds, emodin, Anthrarufin, Alizarine, Aloe- emodin, and Dantron showed the good binding affinity at three different active sites of N-Terminal Domain of SARS-CoV-2 Nucleocapsid Protein and potentially prevent the assembly of virus particles and stop the infection, ADMET prediction revealed that emodin, Anthrarufin, Alizarine, Aloe- emodin, and Dantron are potential drugs for COVID-19 treatment.

\section{Declarations}

Acknowledgements: The authors acknowledge Shoolini University, Solan (India) for providing infrastructure support to conduct the research work. Authors also acknowledge the support provided by Yeast Biology Laboratory, School of Biotechnology, Shoolini University, Solan, India.

Conflict of interest: The authors declare that they have no conflicts of interest.

\section{References}

[1] I.I. Baloch, A. Watts, A.Thomas-Bachli, C. Huber, M.U. Kraemer, K. Khan, Potential for global spread of a novel coronavirus from China. Travel Med. 27, (2020) e011.

[2] D.E. Gordon, G.M. Jang, M. Bouhaddou, J. Xu, K. Obernier, M.J. O'meara, J.Z. Guo, D.L. Swaney, T.A. Tummino, R. Huttenhain, R.M. Kaake, A SARS-CoV-2-human protein-protein interaction map reveals drug targets and potential drug-repurposing. BioRxiv. (2020). https://doi.org/10.1101/2020.03.22.002386.

[3] R. Ramajayam, KP. Tan, P.H. Liang, Recent development of 3C and 3CL protease inhibitors for anticoronavirus and anti-picornavirus drug discovery. Biochem. Soc. Trans.39 (2011) 1371-75.

[4] Wrapp, D., Wang, N., Corbett, K.S., Goldsmith, J.A., Hsieh, C.L., Abiona, O., Graham, B.S. and McLellan, J.S., 2020. Cryo-EM structure of the 2019-nCoV spike in the prefusion conformation. Science, 367(6483) 
[5] S.A. Stohlman, R.S. Baric, G.N. Nelson, L.H. Soe, L.M. Welter, R.J. Deans, Specific interaction between coronavirus leader RNA and nucleocapsid protein. J. Virol. 62(1988) 4280-87.

[6] G.W. Nelson, S.A. Stohlman, S.M. Tahara, High affinity interaction between nucleocapsid protein and leader/intergenic sequence of mouse hepatitis virus RNA. J. Gen. Virol.81 (2000) 181-188.

[7] R. McBride, M. van Zyl, B.C. Fielding,The coronavirus nucleocapsid is a multifunctional protein. Viruses. 6 (2014) 2991-3018.

[8] Y. Cong, M. Ulasli, H. Schepers, M. Mauthe, P. V'kovski, F. Kriegenburg, V. Thiel, C.A. de Haan, F. Reggiori, Nucleocapsid protein recruitment to replication-transcription complexes plays a crucial role in coronaviral life cycle. J. Virol.94 (2020) e-01919-01925.

[9] P.S. Masters, L.S. Sturman, Background paper: functions of the coronavirus nucleocapsid protein. Adv. Exp. Med. Biol.276 (1990) 235-238.

[10] Y.S.Lo, S.Y. Lin, S.M. Wang, C.T. Wang, Y.L. Chiu, T.H. Huang, M.H. Hou, Oligomerization of the carboxyl terminal domain of the human coronavirus 229E nucleocapsid protein. FEBS Letters.587 (2013) 120-127.

[11] I.J. Chen, J.M.P. Yuann, Y.M. Chang, S.Y. Lin, J. Zhao, S. Perlman, Y.Y. Shen, T.H. Huang, M.H. Hou, Crystal structure-based exploration of the important role of Arg106 in the RNA-binding domain of human coronavirus OC43 nucleocapsid protein. Biochimica. Et. Biophysica Acta.1834 (2013)1054-62.

[12] K.S. Saikatendu, J.S. Joseph, V. Subramanian, B.W. Neuman, M.J. Buchmeier, R.C. Stevens, P. Kuhn, Ribonucleocapsid formation of severe acute respiratory syndrome coronavirus through molecular action of the N-terminal domain of N protein. J. Virol.81(2007) 3913-21.

[13] N.E.Grossoehme, L. Li, S.C. Keane, P. Liu, C.E. Dann lii, J.L. Leibowitz, D.P. Giedroc, Coronavirus N protein N-terminal domain (NTD) specifically binds the transcriptional regulatory sequence (TRS) and melts TRS-cTRS RNA duplexes. J. Mol. Biol.394 (2009) 544-57.

[14] Y.W. Tan, S. Fang, H. Fan, J. Lescar, D.X. Liu, Amino acid residues critical for RNA-binding in the Nterminal domain of the nucleocapsid protein are essential determinants for the infectivity of coronavirus in cultured cells. Nucleic Acids Res.34 (2006) 4816-25.

[15] Y.L. Kang, Y.Y. Chou, P.W. Rothlauf, Z. Liu, S. Piccinotti, T.K. Soh, D. Cureton, J.B. Case, R.E. Chen, M.S. Diamond, S.P. Whelan. Inhibition of PIKfyve kinase prevents infection by EBOV and SARS-CoV-2. bioRxiv. (2020).https://doi.org/10.1101/2020.04.21.053058.

[16] J.M. Sanders, M.L. Monogue, T.Z. Jodlowski, J.B. Cutrell, Pharmacologic treatments for coronavirus disease 2019 (COVID-19): a review. Jama. (2020) doi:10.1001/jama.2020.6019. 
[17] E. Gupta, Elucidating the Phytochemical and Pharmacological Potential of Myristicafragrans (Nutmeg). In Ethnopharmacol. Investi. Ind. Spice.(2020) 52-61.

[18] R.K. Ganjhu, P.P. Mudgal, H. Maity, D. Dowarha, S. Devadiga, S. Nag, G. Arunkumar, Herbal plants and plant preparations as remedial approach for viral diseases. Virusdisease. 26 (2015)225-36.

[19] S.Ben-Shabat, L. Yarmolinsky, D. Porat, A. Dahan, Antiviral effect of phytochemicals from medicinal plants: Applications and drug delivery strategies. Drug DelivTransl Res. 10(2020) 354-367.

[20] S. Schwarz, K. Wang, W. Yu, B. Sun, W. Schwarz, Emodin inhibits current through SARS-associated coronavirus 3a protein. Antiviral Research. 90 (2011) 64-69.

[21] T.Y. Ho, S.L. Wu, J.C. Chen, C.C. Li, C.Y. Hsiang, Emodin blocks the SARS coronavirus spike protein and angiotensin-converting enzyme 2 interaction. Antiviral research. 74(2007) 92-101.

[22] S.Jaric, M. Mitrovic, P. Pavlović, Review of ethnobotanical, phytochemical, and pharmacological study of Thymus serpyllum L. Evid. Based Complement. Alternat Med.(2015) 2015.doi.org/10.1155/2015/101978

[23] D. Potdar, R. R. Hirwani, S. Dhulap. Phyto-chemical and pharmacological applications of Berberis aristata. Fitoterapia. 83(2012) 817-830.

[24] P. M. Aja, N. Nwachukwu, U. A. Ibiam, I. O. Igwenyi, C. E. Offor, U. O. Orji, Chemical constituents of Moringa oleifera leaves and seeds from Abakaliki, Nigeria. Am. J. Phytomed. Clin. Ther. 2 (2014) 310-321.

[25] M. Singh, D. Shikha, Zanthoxy/umarmatum DC: Past, present and future prospective. Int. J. Biol. Sci. 7(2017) 21-24.

[26] H. Takooree, M. Z. Aumeeruddy, K. R. Rengasamy, K. N. Venugopala, R. Jeewon, G. Zengin, M. F. Mahomoodally, A systematic review on black pepper (Piper nigrum L.): from folk uses to pharmacological applications. Crit. Rev. Food Sci. Nutr. 59(2019) S210-S243.

[27] N. Sharma, V. Kumar, M. P. Chopra, A. Sourirajan, K. Dev, Thalictrum foliolosum: A lesser unexplored medicinal herb from the Himalayan region as a source of valuable phytocompounds. J. Ethnopharmacol.255 (2020)e112736.

[28] G.R. Fenwick, A.B. Hanley, Allium species poisoning. Vet Rec. (1985) 116:28.

[29] Y. Meng, D. Lu, N. Guo, L. Zhang, G. Zhou, Anti-HCMV effect of garlic components. Virol Sin. 8 (1993) 147-150.

[30] G. Nai-Lan, L. Cao-Pei, G.L. Woods, E. Reed, Z. Gui-Zhen, Z. Li-Bi, R.H. Waldman, Demonstration of antiviral activity of garlic extract against human cytomegalovirus in vitro. Chin. Med. J. 106 (1993) 9396. 
[31] Y. Tsai, L.L. Cole, L.E. Davis, S.J. Lockwood, V. Simmons, G.C. Wild, Antiviral properties of garlic: in vitro effects on influenza B, herpes simplex and coxsackie viruses. Planta Med. 5 (1985) 460-461.

[32] N.D. Weber, D.O. Andersen, J.A. North, B.K. Murray, L.D. Lawson, B.G. Hughes, In vitro virucidal effects of Allium sativum (garlic) extract and compounds. Planta Med. 58 (1992) 417-423.

[33] V.Georgiev, A. Stefanov, M. Tarulli, Smoothing-Strichartz estimates for the Schrodinger equation with small magnetic potential. arXiv preprint math. (2005) e0509416.

[34] G. Lanka. R. Bathula, M. Dasari, S. Nakkala, M. Bhargavi, G. Somadi, S.R. Potlapally. Structure-based identification of potential novel inhibitors targeting FAM3B (PANDER) causing type 2 diabetes mellitus through virtual screening. J. Recept. Sig. Transd. 39 (2019) 253-263.

[35] S. Kalyaanamoorthy,Y.P. Chen. Structure-based drug design to augment hit discovery. Drug Discov. Today. 16(2011) 831-839.

[36] E. Lionta, G. Spyrou, D.K. Vassilatis, Z. Cournia,Structure-based virtual screening for drug discovery: principles, applications and recent advances. CTMC. 14(2014) 1923-1938.

[37] V. Ramatenki, S.R. Potlapally, R.K. Dumpati, R. Vadija, U. Vuruputuri, Homology modeling and virtual screening of ubiquitin conjugation enzyme E2A for designing a novel selective antagonist against cancer. J Recept Signal Transduct Res. 35(2015):536-549.

[38] S.K.Tripathi, R. Muttineni, S.K. Singh. Extra precision docking, free energy calculation and molecular dynamics simulation studies of CDK2 inhibitors. J. Theor. Biol. 334 (2013) 87-100.

[39] P. Banerjee, A.O. Eckert, A.K. Schrey, R. Preissner, ProTox-II: a webserver for the prediction of toxicity of chemicals. Nucleic Acids Res. Spec. Publ. 46 (2018) W257-W263.

[40] K. Dev, V. Kumar, R. Rolta, A. Sharma, Herbal Pharmaceutical Excipient for Enhancing Antifungal and Antibacterial Properties of Existing Drugs. Indian Patent Filing Number: 201711028454. (2017).

[41] R. Rolta, A. Sharma, V. Kumar, A. Sourirajan, D.J. Baumler, K. Dev, Methanolic Extracts of the Rhizome of $R$. emodi Act as Bioenhancer of Antibiotics against Bacteria and Fungi and Antioxidant Potential. Med. Plant. 8(2018) 74-85.

[42] R. Rolta, V. Kumar, A. Sourirajan, N.K. Upadhyay, K. Dev, Bioassay guided fractionation of rhizome extract of Rheum emodi wall as bio-availability enhancer of antibiotics against bacterial and fungal pathogens. J. Ethnopharmacol. 257 (2020)e112867.

[43] O.S. Oladeji, F.E. Adelowo, D.T. Ayodele, K.A. Odelade. Phytochemistry and pharmacological activities of Cymbopogon citratus. a review. Scientific African. 6 (2019)e00137. 
[44] S.K.Pal, P.K. Mukherjee, K. Saha, M. Pal, B.P. Saha, Antimicrobial action of the leaf extract of Moringa oleifera Lam. Anc. Sci. Life.14 (1995)197.

[45] D.Kumar, V., S. Raj, B. Rathi,In silico identification of potent FDA approved drugs against Coronavirus COVID-19 main protease: A drug repurposing approach. Chem. Biol. Lett. 7(2020) 166-75.

[46] N. Latha, M. Pandit. In silico studies reveal potential antiviral activity of phytochemicals from medicinal plants for the treatment of COVID-19 infection. (2020). DOI: 10.21203/rs.3.rs-22687/v1

[47] Tatara, Kemal, Investigation of the N-Terminal Domain of SARS-CoV-2 Nucleocapsid Protein with Antiviral Compounds Based on Molecular Modeling Approach.ScienceOpen Preprints. (2020). DOI: 10.14293/S2199-1006.1.SOR-.PPPT99I.v1.

[48] A. Ubani,F. Agwom, N.Y. Shehu, P. Luka, E.A. Umera, U. Umar, S. E. Omale, Nnadi, J.C. Aguiyi. Molecular Docking Analysis of Some Phytochemicals on Two SARS-CoV-2 Targets. bioRxiv. (2020).doi: https://doi.org/10.1101/2020.03.31.017657.

[49] S. Ahmed, A.M. Shohael,In silico studies of four anthraquinones of Senna alataL. as potential antifungal compounds. Pharmacologyonline. 2 (2019) 259-268.

[50] Andrew D. Davidson, Maia Kavanagh Williamson, Sebastian Lewis, Deborah Shoemark, Miles W. Carroll, Kate Heesom, Maria Zambon, Joanna Ellis, Phillip A. Lewis, Julian A. Hiscox, David A. Matthews, Characterisation of the transcriptome and proteome of SARS-CoV-2 using direct RNA sequencing and tandem mass spectrometry reveals evidence for a cell passage induced in-frame deletion in the spike glycoprotein that removes the furin-like cleavage site. bioRxiv 2020.03.22.002204; doi: https://doi.org/10.1101/2020.03.22.002204

\section{Tables}

Table 1:Ramachandran Plot statistics showing favored regions in RNA binding domain of nucleocapsid phosphoprotein from SARS coronavirus 2 (PDB ID: 6VYO)

\begin{tabular}{|l|c|c|}
\hline \multirow{2}{*}{ Properties } & RNA binding domain of nucleocapsid phosphoprotein from SARS coronavirus 2(6YVO) \\
\cline { 2 - 3 } & Residues & $\%$ \\
\hline The Most favored regions & 358 & 92.5 \\
\hline Additional allowed regions & 29 & 7.5 \\
\hline Generously allowed regions & 0 & 0 \\
\hline Disallowed regions & 0 & - \\
\hline $\begin{array}{l}\text { The End residues } \\
\text { (excluding Glycine and Proline) }\end{array}$ & 8 & - \\
\hline Proline & 64 & - \\
\hline Glycine & 40 & 100 \\
\hline Total number of residues & 499 & \\
\hline
\end{tabular}


Table 2:Amino acids involved in active sites of RNA binding domain of nucleocapsid phosphoprotein from SARS coronavirus 2 (PDB ID: 6VYO).

\begin{tabular}{|c|c|c|c|c|}
\hline $\begin{array}{l}\text { Active } \\
\text { Sites }\end{array}$ & $\begin{array}{l}\text { D } \\
\text { Score }\end{array}$ & Size & $\begin{array}{l}\text { Site } \\
\text { Score }\end{array}$ & Chains and amino acid residues numbers \\
\hline Site-A & 1.039 & 216 & 1.009 & $\begin{array}{l}\text { CHAIN A: ALA 50, SER 51, PHE 53, THR 54, ALA 55, LEU 56, THR 57, HIP 59, ARG 92, SER 105, ARG 107, TYR } \\
\text { 109, ARG 149, ALA 156, ILE 157, VAL 158, GLN 160, LEU 161, PRO 162, GLN 163,GLY 164, THR 165, LEU 167, } \\
\text { PHE 171, TYR 172,ALA } 173 \\
\text { CHAIN B: TRP 52, PHE 53, PRO 73, ILE 74, ASN 75, THR 76, ASN 77, SER 78, ASP 82, HIE 145, ILE 146, } \\
\text { THR148, ARG 149, ASN 150, ASN 153, ASN 154, ALA 155, VAL 158, LEU 159, GLN 160, ILE } 157\end{array}$ \\
\hline Site-B & 0.99 & 196 & 0.98 & $\begin{array}{l}\text { CHAIN A: TPR 52, PHE 53, PRO 73, ILE 74, ASN 75, THR 76, ASN 77, TYR112, GLY 114, THR 115, GLY 116, } \\
\text { ALA 119, ASP 144, HIE 145, ILE 146, GLY 147, THR 148, ARG 149, ASN 150, ASN 153, ASN 154, ILE 157, VAL } \\
\text { 158, LEU 159, GLN } 160 \\
\text { CHAIN D: THR 54, ALA 55, THR 57, HIE 59, ALA 90, THR 91, ARG 92, ILE 94, GLY 96, GLY 97, ASP 98, LYS } \\
\text { 102, LEU 104, SER 105, PRO 106, ARG 107, TYR 109, VAL 158, LEU 159, GLN 160, LEU 161, GLN 163, THR } \\
\text { 165, THR 166, LEU 167, ALA } 173\end{array}$ \\
\hline Site-C & 1.045 & 183 & 1.039 & $\begin{array}{l}\text { CHAIN C: ALA 50, SER 51, PHE 53, THR 54, ALA 55, LEU 56, THR 57, HIP 59, ARG 92,ARG 107, TYR 109, ARG } \\
\text { 149, ALA 156, ILE 157, VAL } 158 \\
\text { CHAIN D: TRP 53, PRO 73, ILE 74, ASN 75, THR 76, ASN 77, SER 78, ASP 82, HIE 145, ILE 146, GLY 146, THR } \\
\text { 148, ARG 149, ASN 150, ASN 153, ASN 154, ALA155, ILE157, VAL158, LEU159, GLN160 }\end{array}$ \\
\hline
\end{tabular}

Each amino acid residue is numbered followed by three letter code. Amino acid residues in red are the phosphorylation sites on Serine and Threonine were predicted by Davidson et al (2020) https://doi.org/10.1101/2020.03.22.002204doi [50]. Nonstandard amino acids are CL, GOL, $\mathrm{HOH}, \mathrm{MES}, \mathrm{ZN}$.

Table 3: List of hundred major phytocompounds (numbered 1-100) of 10 medicinal plants with pharmacological properties 


\begin{tabular}{|c|c|c|c|}
\hline No & $\begin{array}{l}\text { Medicinal } \\
\text { Plants }\end{array}$ & $\begin{array}{l}\text { Pharmacological } \\
\text { properties }\end{array}$ & $\begin{array}{l}\text { Major phytocompounds } \\
\text { Selected for the current study }\end{array}$ \\
\hline & $\begin{array}{l}\text { Rheum } \\
\text { emodi }\end{array}$ & $\begin{array}{l}\text { Treatment of Severe } \\
\text { Acute Respiratory } \\
\text { Syndrome (SARS) [21, } \\
\text { 22].Antioxidant, } \\
\text { antibacterial antifungal } \\
\text { and Bioenhancer of } \\
\text { antibiotics }[40,41,42] .\end{array}$ & $\begin{array}{l}\text { (1) Alizarin, (2) Aloe-emodin, (3) Anthraquinone, (4) Anthrarufin, (5) Anthrone, (6) } \\
\text { Chryophanol, (7) Clicoemodin, (8) Dantron, (9) Emodin, (10) Gallic acid, (11) Juglone, } \\
\text { (12) Physicon, (13) Piceatannol, (14) Quinizarin, (15) Rubiadin }\end{array}$ \\
\hline & $\begin{array}{l}\text { Thymus } \\
\text { serpyllum }\end{array}$ & $\begin{array}{l}\text { Antimicrobial, antiviral, } \\
\text { antioxidant, anti- } \\
\text { inflammatory and anti- } \\
\text { carcinogenic [22] }\end{array}$ & $\begin{array}{l}\text { (16) 3-Octanone, (17) 8-Prenylnaringenin, (18) Apigenin, (19) Apigenin-7-O-glucoside, } \\
\text { (20) Bornyl acetate, (21) Camphene, (22) Camphor, (23) Carvacrol, (24) Caryophyllene } \\
\text { oxide, (25) Catechin, (26) Eriodictyol, (27) Eriodictyol-7-glucuronide, (28) Geranyl } \\
\text { acetate, (29) Linalool, (30) Myrcene, (31) Rutin, (32) Spathulenol, (33) Taxifolin, (34) } \\
\text { Thymol, (35) trans-Nerolidol, (36) } \alpha \text {-Pinene, (37) } \beta \text {-Bisabolene, (38) } \beta \text {-Caryophyllene, } \\
\text { (39) } \beta \text {-Pinene, (40) } \delta \text {-Cadinene. }\end{array}$ \\
\hline & $\begin{array}{l}\text { Cymbopogon } \\
\text { citrates }\end{array}$ & $\begin{array}{l}\text { Anti-obesity, anti- } \\
\text { bacterial, anti-fungal, } \\
\text { anti-nociceptive, anti- } \\
\text { oxidants anti-diarrheal, } \\
\text { and anti-inflammatory } \\
\text { [25] }\end{array}$ & $\begin{array}{l}\text { (41) Citral alpha, (42) citronellal, (43) Geraniol, (44) lemonene, (45) nerol, (46) } \\
\text { terpinolene }\end{array}$ \\
\hline & $\begin{array}{l}\text { Moringa } \\
\text { oleifera }\end{array}$ & $\begin{array}{l}\text { Antimicrobial }[44] \\
\text { antiviral potential }[24]\end{array}$ & (47) Glucomoringin, (48) Niazinicin A, (49) Niazinin, (50) Pterygospermin \\
\hline & $\begin{array}{l}\text { Thalictrum } \\
\text { foliolosum }\end{array}$ & $\begin{array}{l}\text { antiplasmodial, antiviral, } \\
\text { antibacterial and anti- } \\
\text { gastric ulcer activity [27] }\end{array}$ & $\begin{array}{l}\text { (51) 8-Oxyberberine, (52) Berberine, (53) Jatrorrhizine, (54) Noroxyhydrastinine, (55) } \\
\text { Palmatine, (56) Thalicarpine, (57) Thalidasine, (58) Thalirugidine, (59) Thalirugine, (60) } \\
\text { Thalisopine, (61) Thalrugosaminine, (62) Thalrugosidine }\end{array}$ \\
\hline & $\begin{array}{l}\text { Berberis } \\
\text { aristata }\end{array}$ & $\begin{array}{l}\text { Anti-diabetic, anti- } \\
\text { microbial, anti-cancer, } \\
\text { antilipidemic, anti-HIV, } \\
\text { anti-pyretic [23] }\end{array}$ & $\begin{array}{l}\text { (63) Berbamine, (64) Columbamine, (65) Isocorydine, (66) Lambertine, (67) Lupeol, } \\
\text { (68) Oleanolic acid, (69) Oxyberberine, (70) Oxycanthine, (71) Stigmasterol }\end{array}$ \\
\hline & Piper nigrum & $\begin{array}{l}\text { Antimicrobial, } \\
\text { antioxidant, anticancer, } \\
\text { analgesic, anticonvulsant, } \\
\text { neuroprotective, } \\
\text { hypoglycemic, } \\
\text { hypolipidemic, and anti- } \\
\text { inflammatory activities } \\
\text { [26] }\end{array}$ & $\begin{array}{l}\text { (72) Sabinene, (73) Piperolein B, (74) Piperolein A, (75) Piperine, (76) Piperazine, (77) } \\
\text { Guaiol, (78) b-caryophyllene }\end{array}$ \\
\hline & $\begin{array}{l}\text { Allium } \\
\text { sativum }\end{array}$ & $\begin{array}{l}\text { Anti-influenza A and B } \\
{[28], \text { antiviral }[29,30,31]}\end{array}$ & (79) Vinyllithium, (80) Alliin, (81) Allicin, (82) (Z)-Ajoene, (83) (E)-Ajoene \\
\hline & $\begin{array}{l}\text { Myristica } \\
\text { fragrans }\end{array}$ & $\begin{array}{l}\text { Antioxidant, } \\
\text { antimicrobial, } \\
\text { aphrodisiac, anticancer, } \\
\text { hepatoprotective, anti- } \\
\text { inflammatory, } \\
\text { antidepressant, and } \\
\text { cardioprotective activity } \\
\text { [18] }\end{array}$ & $\begin{array}{l}\text { (84) Trimyristin, (85) safrole, (86) Sabinene, (87) myristicin, (88) methoxyeugenol, (89) } \\
\text { meso-dihydroguaiaretic acid, (90) isoelemicin, (91) elemicin, (92) camphene, (93) 9- } \\
\text { epoxylignan, (94) 4-terpinol }\end{array}$ \\
\hline ). & $\begin{array}{l}\text { Zanthoxylum } \\
\text { armatum }\end{array}$ & $\begin{array}{l}\text { Antifungal, antibacterial, } \\
\text { antiviral, anti- } \\
\text { inflammatory, anti- } \\
\text { oxidant, cardiovascular } \\
\text { and immunomodulatory } \\
\text { [25] }\end{array}$ & $\begin{array}{l}\text { (95) } \beta \text {-Sitosterol- } \beta \text {-D-Glucoside, (96) Xanthyletin, (97) Tambulin, (98) Sesamin, (99) } \\
\text { Bergapten, (100) Armatamide }\end{array}$ \\
\hline
\end{tabular}


Table 4: Interacting amino acids and docking score of phytocompounds with binding site A (1.039) of 6VY0

\begin{tabular}{|c|c|c|c|c|c|}
\hline $\begin{array}{l}\text { ind } \\
\text { ). }\end{array}$ & $\begin{array}{l}\text { Name of Ligand } \\
\text { (Plant source) }\end{array}$ & $\begin{array}{c}\Delta \mathrm{G} \text { Bind (kcal } \\
\left.\mathrm{mol}^{-1}\right)\end{array}$ & $\begin{array}{l}\text { Docking } \\
\text { Score }\end{array}$ & H-bond & Interactive Residues \\
\hline & $\begin{array}{l}\text { Aloe- emodin } \\
(\text { Rheum emodi) }\end{array}$ & -25.45 & -8.508 & $\begin{array}{l}\text { Chain A: ARG } 107 \\
\text { Chain B: HIE 145, ASN } \\
\text { 75, ASN } 77\end{array}$ & $\begin{array}{l}\text { Chain A: LEU 159, VAL 158, THR 54, ALA 55, THR 57, HIP 59, } \\
\text { ARG 92, ARG } 107 \\
\text { Chain B:SER 78, ILE 157, ASN 154, TRP 52, ILE 146, HIE 145, } \\
\text { ASN 75, ASN } 77\end{array}$ \\
\hline & $\begin{array}{l}\text { Anthrarufin } \\
(\text { Rheum emodi) }\end{array}$ & -38.099 & -8.456 & $\begin{array}{l}\text { Chain A: - } \\
\text { Chain B: } \quad \text { ASN } 75\end{array}$ & $\begin{array}{l}\text { Chain A: THR 54, ALA 55, THR 57, HIP 59, ARG 92, ARG 107, } \\
\text { VAL } 152 \\
\text { Chain B: TRP 52, ASN 154, ILE 157, ASN 77, SER 78, ILE } \\
\text { 146, HIE 145, ASP 82, ASN } 75\end{array}$ \\
\hline & $\begin{array}{l}\text { Alizarine } \\
\text { (Rheum emodi) }\end{array}$ & -31.2891 & -8.441 & $\begin{array}{l}\text { Chain A: } \quad \text { ASN } 75 \\
\text { Chain B: } \quad \text { ASN 77, ASN } \\
\text { 75, HIE } 145\end{array}$ & $\begin{array}{l}\text { Chain A: ARG 107, HIP 59, ARG 92, ALA 55, THR 54, LEU 159, } \\
\text { VAL 158, ASN 75 } \\
\text { Chain B: TRP 52, TYR 112, ILE 157, ASN 154, SER 78, ILE } \\
\text { 146, HIE 145, ASN 77, ASN } 75\end{array}$ \\
\hline & $\begin{array}{l}\text { Dantron } \\
(\text { Rheum emodi) }\end{array}$ & -39.8129 & -8.322 & 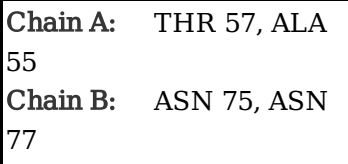 & $\begin{array}{l}\text { Chain A: HIP 59, LEU 56, THR 54, ARG 107, LEU 159, VAL } \\
\text { 158, THR 57, ALA 55 } \\
\text { Chain B: ASP 82, HIE 145, ILE 146, SER 78, TRP 52, ILE 157, } \\
\text { ASN 75, ASN } 77\end{array}$ \\
\hline & $\begin{array}{l}\text { Emodin } \\
(\text { Rheum emodi) }\end{array}$ & -43.87 & -8.299 & $\begin{array}{l}\text { Chain A: ALA } 55 \\
\text { Chain B: ASN 77, ASN } \\
75\end{array}$ & $\begin{array}{l}\text { Chain A: VAL 158, LEU 159, THR 54, LEU 56, HIP 59, ARG } \\
\text { 107, ALA } 55 \\
\text { Chain B: ASP 82, ILE 157, TRP 52, SER 78, HIE 145, ILE 146, } \\
\text { ASP 82, ASN 77, ASN } 75\end{array}$ \\
\hline
\end{tabular}

Each amino acid residue is numbered followed by three letter code. Amino acid residues in red are the phosphorylation sites on Serine and Threonine were predicted by Davidson et al (2020) https://doi.org/10.1101/2020.03.22.002204doi[50].

Table 5:Interacting amino acids and docking score of phytocompounds with binding site B (0.99) 


\begin{tabular}{|c|c|c|c|c|c|}
\hline $\begin{array}{l}\text { Compound } \\
\text { CID no. }\end{array}$ & $\begin{array}{l}\text { Nameof } \\
\text { Ligand } \\
\text { (Plant } \\
\text { source) }\end{array}$ & $\begin{array}{c}\Delta \mathrm{G} \mathrm{Bind} \\
\left(\mathrm{kcal} \mathrm{mol}{ }^{-1}\right)\end{array}$ & $\begin{array}{c}\text { Docking } \\
\text { Score }\end{array}$ & H-bond & Interactive Residues \\
\hline 3220 & $\begin{array}{l}\text { Emodin } \\
(\text { Rheum } \\
\text { emodi })\end{array}$ & -40.60 & -7.714 & $\begin{array}{ll}\text { Chain A: } & \text { HIE 145, ASN 77, ASN 75, ASN } 154 \\
\text { Chain D: } & \text { ARG 92 }\end{array}$ & $\begin{array}{l}\text { Chain A: ILE 146, SER 78. TRP 52, ILE 157, HIE 145, } \\
\text { ASN 77, ASN 75, ASN } 154 \\
\text { Chain D: HIE 59, ALA 173, THR 57, LEU 104, SER } \\
\text { 105, ARG 107, ARG } 92\end{array}$ \\
\hline 2950 & $\begin{array}{l}\text { Dantron } \\
\text { (Rheum } \\
\text { emodi) }\end{array}$ & -45.48 & -6.99 & $\begin{array}{l}\text { Chain A: ASN 154, ILE 146, ASN } 77 \\
\text { Chain D: NA }\end{array}$ & $\begin{array}{l}\text { Chain A: TRP 52, ASN 75, ULE 157, HIE 145, ASN } \\
\text { 75, SER 78, ASN 154, ILE 146, ASN } 77 \\
\text { Chain D: ARG 107, SER 105, LEU 104, ARG } 92\end{array}$ \\
\hline 6293 & $\begin{array}{l}\text { Alizarine } \\
\text { (Rheum } \\
\text { emodi) }\end{array}$ & -33.59 & -6.598 & $\begin{array}{ll}\text { Chain A: } & \text { ASN 77, ASN } 75 \\
\text { Chain D: } & \text { NA }\end{array}$ & $\begin{array}{l}\text { Chain A: ILE 146, HIE 145, ARG 92, SER 78, TRP 52, } \\
\text { ILE 157, ASN 154, ASN 77, ASN } 75 \\
\text { Chain D:SER 105, ARG 107, HIE 59, THR } 57\end{array}$ \\
\hline 10207 & $\begin{array}{l}\text { Aloe- } \\
\text { emodin } \\
(\text { Rheum } \\
\text { emodi) }\end{array}$ & -36.92 & -6.433 & $\begin{array}{l}\text { Chain A: ASN 154, ILE 157, SER 78, ILE 146, } \\
\text { HIE 145, TRP 52, ASN 75, ASN } 77 \\
\text { Chain D: NA }\end{array}$ & $\begin{array}{l}\text { Chain A: ASN 154, ILE 157, SER 78, ILE 146, HIE } \\
\text { 145, TRP 52, ASN 75, ASN } 77 \\
\text { Chain D: ARG 107, SER 105, LEU 104, ARG 92, HIE } \\
\text { 59, THR } 57\end{array}$ \\
\hline 8328 & $\begin{array}{l}\text { Anthrarufin } \\
\text { (Rheum } \\
\text { emodi) }\end{array}$ & -34.9567 & -6.354 & $\begin{array}{ll}\text { Chain A: } & \text { ASN } 77 \\
\text { Chain D: } & \text { NA }\end{array}$ & $\begin{array}{l}\text { Chain A:SER 78, ASN 75, TRP 52, ILE 146, ILE 157, } \\
\text { ASN } 77 \\
\text { Chain D: ARG 107, SER 105, ARG 92, THR 57, HIE } \\
59\end{array}$ \\
\hline
\end{tabular}

Each amino acid residue is numbered followed by three letter code. Amino acid residues in red are the phosphorylation sites on Serine and Threonine predicted by Davidson et al (2020) https:// doi.org/10.1101/2020.03.22.002204doi[50].

Table 6: Interacting amino acids and docking score of phytocompounds with binding site-C (1.045) 


\begin{tabular}{|c|c|c|c|c|c|}
\hline id & $\begin{array}{l}\text { Name of Ligand } \\
\text { (Plant source) }\end{array}$ & $\begin{array}{l}\Delta \mathrm{G} \text { Bind } \\
\left(\mathrm{kcal} \mathrm{mol}^{-1}\right)\end{array}$ & $\begin{array}{c}\text { Docking } \\
\text { Score }\end{array}$ & No. of H-bond & Interactive Residues \\
\hline & $\begin{array}{l}\text { Anthrarufin } \\
\text { (Rheum emodi) }\end{array}$ & -39.48 & -8.538 & $\begin{array}{l}\text { Chain C: - } \\
\text { Chain D: ASN 75, } \\
\text { ASN } 77\end{array}$ & $\begin{array}{l}\text { Chain C: TTR 54, ALA 55, THR 57, HIP 59, ARG 107, ARG } 92 \\
\text { Chain D: TRP 52, ASN 154, ILE 157,HIS 145, ILE 146, SER 78, ASP } \\
\text { 82, ASN 75, ASN } 77\end{array}$ \\
\hline & $\begin{array}{l}\text { Aloe- emodin } \\
\text { (Rheum emodi) }\end{array}$ & -32.61 & -8.508 & $\begin{array}{l}\text { Chain C: THR 57, } \\
\text { LEU } 159 \\
\text { Chain D: ASN } 75\end{array}$ & $\begin{array}{l}\text { Chain C: HIP 59, LEU 56, ALA 55, THR 54, VAL 158, LEU 159, THR } \\
\text { 57, LEU } 159 \\
\text { Chain D: ASN 77, SER 78, ASN 154, ILE 157, VAL 158, LEU 159, ILE } \\
\text { 146, HIS 145, ARG 107, ASN 75, ASN } 75\end{array}$ \\
\hline & $\begin{array}{l}\text { Alizarine } \\
\text { (Rheum emodi) }\end{array}$ & -33.84 & -8.441 & $\begin{array}{l}\text { Chain C: ALA 55, } \\
\text { LEU 56, THR } 57 \\
\text { Chain D: ASN } 75\end{array}$ & $\begin{array}{l}\text { Chain C: THR 54, LEU 159, VAL 158, ALA 55, LEU 56, THR } 57 \\
\text { Chain D: HIS 145, ILE 146, ASN 77, SER 78, ASN 154, ILE 157, TRP } \\
\text { 52, TYR 112, ASN } 75\end{array}$ \\
\hline & $\begin{array}{l}\text { Dantron } \\
\text { (Rheum emodi) }\end{array}$ & -35.459 & -8.322 & $\begin{array}{l}\text { Chain C: THR 57, } \\
\text { ALA } 55 \\
\text { Chain D: - }\end{array}$ & $\begin{array}{l}\text { Chain C: HIP 59,THR 57, LEU 56, ALA 55, THR 54, ARG 107, VAL } \\
\text { 158, LEU } 159 \\
\text { Chain D: HIS 145, ILE 146, TRP 52, SER 78, ASN 77, ASN 154, ILE } \\
\text { 157, ASP } 82\end{array}$ \\
\hline & $\begin{array}{l}\text { Emodin } \\
\text { (Rheum emodi) }\end{array}$ & -32.78 & -8.299 & $\begin{array}{l}\text { Chain C: ARG } 107 \\
\text { Chain D: ILE 146, } \\
\text { ASN } 175\end{array}$ & $\begin{array}{l}\text { Chain C: TYR 109, ARG 107, ARG 92, HIP 59, THR 57, ALA 55, THR } \\
57 \\
\text { Chain D: ASN 153, ASN 154, ILE 146, HIS 145, TRP 52, ASP 82, SER } \\
\text { 79, SER 77, ASN } 75\end{array}$ \\
\hline
\end{tabular}

Each amino acid residue is numbered followed by three letter code. Amino acid residues in red are the phosphorylation sites on Serine and Threonine predicted by Davidson et al (2020) https://doi.org/10.1101/2020.03.22.002204doi [50].

Table 7: ADME properties of selected phytocompounds predicted by SwissADME. 


\begin{tabular}{|c|c|c|c|c|c|c|c|c|c|}
\hline \multirow[b]{2}{*}{ Compounds } & \multicolumn{5}{|c|}{ SwissADME } & \multirow[b]{2}{*}{ Ghose Rule } & \multirow[b]{2}{*}{$\begin{array}{l}\text { Veber } \\
\text { Rule }\end{array}$} & \multirow[b]{2}{*}{$\begin{array}{l}\text { Egan } \\
\text { Rule }\end{array}$} & \multirow[b]{2}{*}{$\begin{array}{c}\text { Muegge } \\
\text { Rule }\end{array}$} \\
\hline & $\begin{array}{l}\text { Consensus } \\
\text { Log } \mathrm{P}_{\mathrm{O} / \mathrm{W}}\end{array}$ & Water Solubility & GI Absorption & Lipinski Rule & TPSA ( $(\AA 2)$ & & & & \\
\hline Emodin & 1.87 & Soluble & High & Yes & 94.83 & Yes & Yes & Yes & Yes \\
\hline Anthrarufin & 2.16 & Moderately soluble & High & Yes & 74.60 & Yes & Yes & Yes & Yes \\
\hline Alizarine & 2.02 & Soluble & High & Yes & 74.60 & Yes & Yes & Yes & Yes \\
\hline Aloe- emodin & 1.50 & Soluble & High & Yes & 94.83 & Yes & Yes & Yes & Yes \\
\hline Dantron & 2.04 & Soluble & High & Yes & 74.60 & Yes & Yes & Yes & Yes \\
\hline
\end{tabular}

Table 8: Toxicity prediction of active phytocompounds predicted by admetSAR and PROTOX-II software

\begin{tabular}{|l|l|l|l|l|}
\hline \multirow{2}{*}{ Phytocompounds } & \multicolumn{2}{|c|}{ admet SAR } & \multicolumn{2}{c|}{ Protox II } \\
\cline { 2 - 5 } & Carcinogens & Rate Acute toxicity $\left(\mathrm{LD}_{50}\right) \mathrm{kg} \mathrm{mol}^{-1}$ & $\mathrm{LD}_{50}{\text { ( } \mathrm{mg} \mathrm{kg}^{-1} \text { ) }}^{\text {Cytotoxicity }}$ & (n) \\
\hline Emodin & non-carcinogen & & $\begin{array}{l}5000 \\
\text { (Class 5) }\end{array}$ & Inactive \\
\hline Anthrarufin & Non-carcinogen & 2.5826 (III) & $\begin{array}{l}5000 \\
\text { (class 5) }\end{array}$ & Inactive \\
\hline Alizarine & Non-carcinogen & 2.8601 (III) & $\begin{array}{l}7000 \\
\text { (class 5) }\end{array}$ & Inactive \\
\hline Aloe- emodin & Non-carcinogen & 2.5292 (III) & $\begin{array}{l}5000 \\
\text { (class 5) }\end{array}$ & Inactive \\
\hline Dantron & Non-carcinogen & 2.9280 (II) & $\begin{array}{l}7000 \\
\text { (class 6) }\end{array}$ & Inactive \\
\hline
\end{tabular}

\section{Figures}




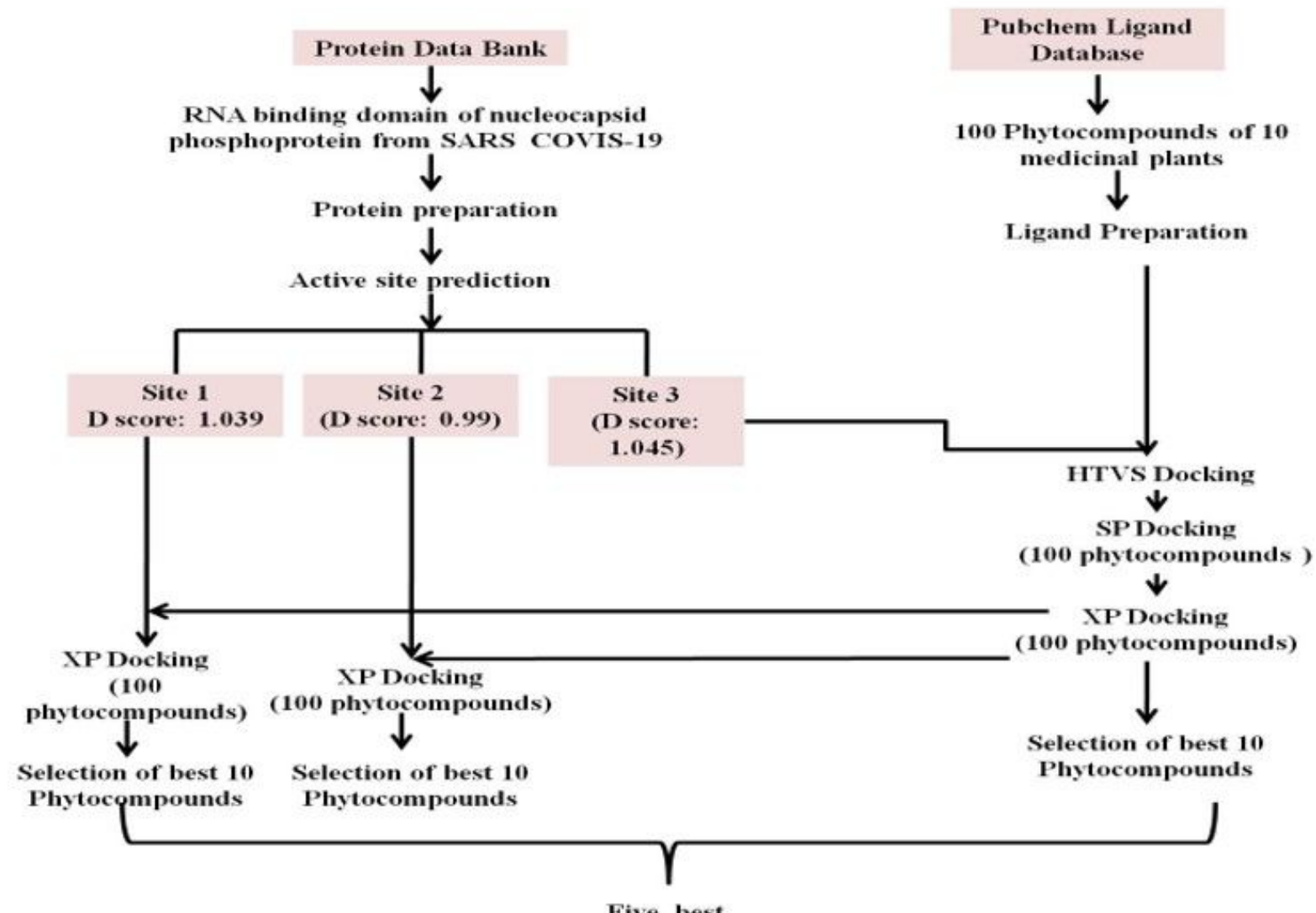

Five best

phytocompounds

\section{Figure 1}

Schematic of the experiments followed in the current study. 
A
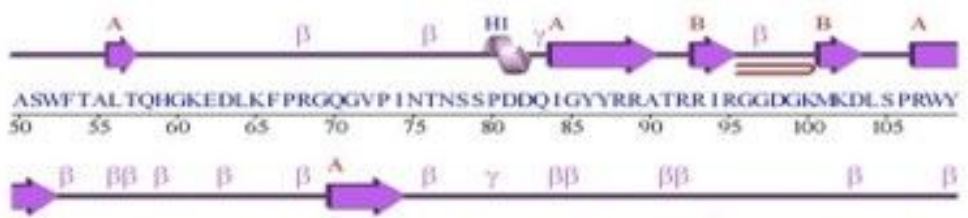

FYYLGTGPEAGL PYGANKDGI IWVATEGALNTPKDHIGTRNPANNAAIVLOL POOTTLPK

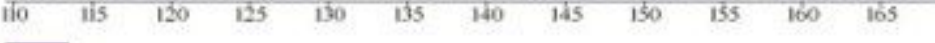
$\overline{\frac{\text { GFYA }}{170}}$

B

C
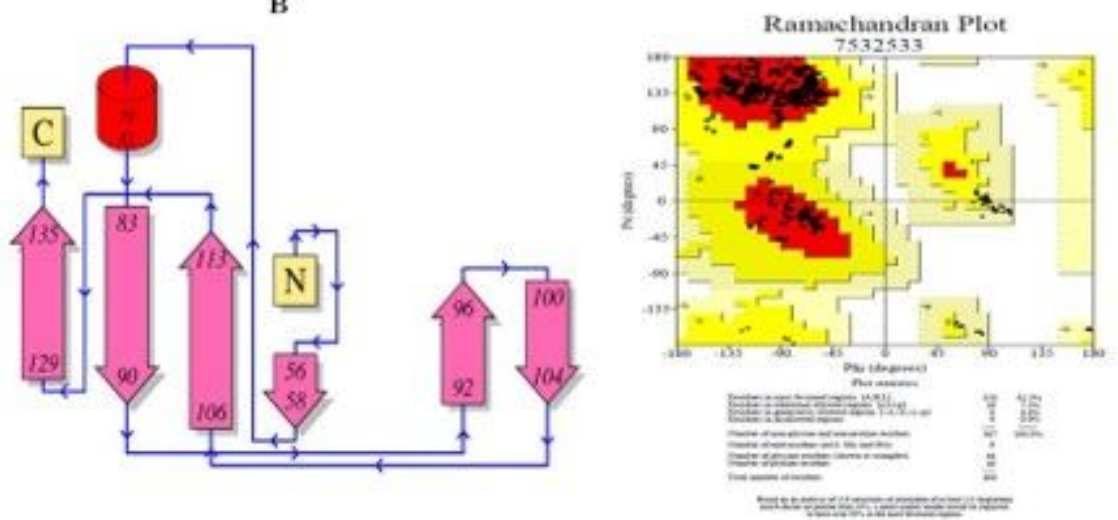

\section{Figure 2}

A) Secondary structure of NTD (amino acid residues 50-173) of RNA binding domain of nucleocapsid phosphoprotein from SARS coronavirus 2 (PDB ID: 6VYO); B) Topology of secondary structure and C)The Ramachandran plot describes the favored and disfavored regions of residues. The maximum $(92.5 \%)$ residues are located in an allowed region. 


\section{A}

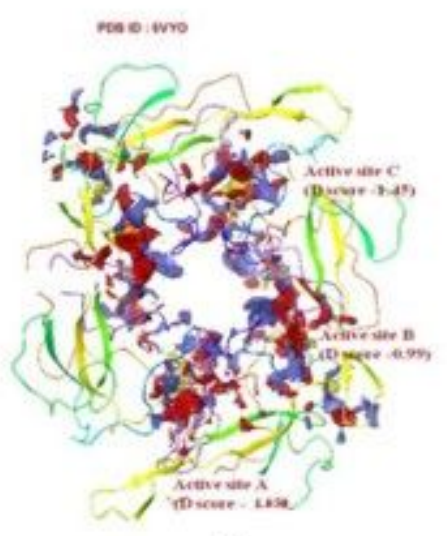

B

c
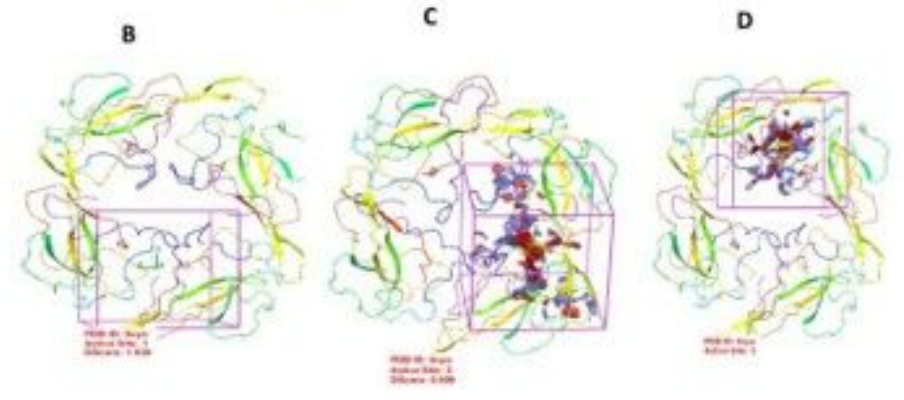

\section{Figure 3}

Active site prediction. 3-D structure representation of tetrameric RNA binding domain (N-terminal domain) of nucleocapsid phosphoprotein from SARS coronavirus 2 (PDB ID: 6VYO) showing threepredicted binding sites shown as Active site A, Active site B and Active site $C(A)$. Panel B, C, and D represent tetramericRNA binding domain showing each active site as indicated.

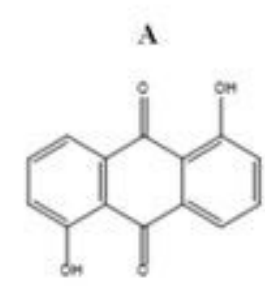

D<smiles>Cc1cccc2c1[C@H](C)C1C(=CC=CC1C)C2C</smiles>

B

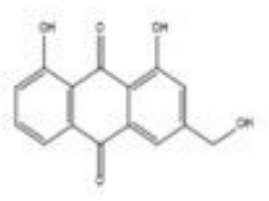

E

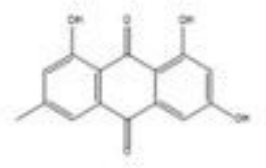

c<smiles>CC1CCC2C(C)C3CCCCC3C(C)C2C1C</smiles>

\section{Figure 4}


Structure of potential phytocompounds of R. emodi: A) Anthrarufin, (B) Aloe- emodin, (C) Alizarine,(D) Dantron,(E) Emodin.

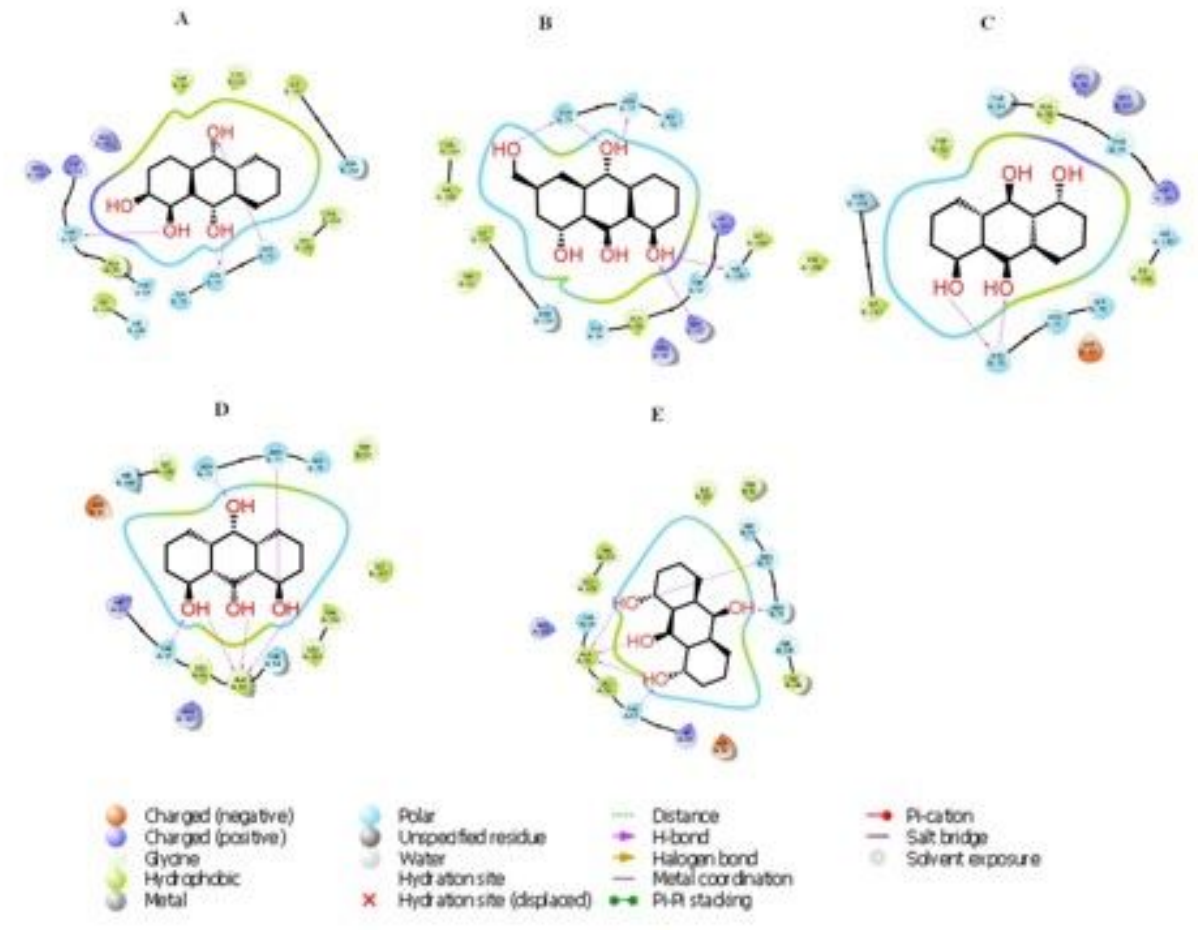

\section{Figure 5}

The 2D molecular interactions of best 5 phytocompounds with active site A of 6VYO: (A) Alizarin, (B) Aloe- emodin, (C) Anthrarufin (D), Dantron, (E) Emodin.

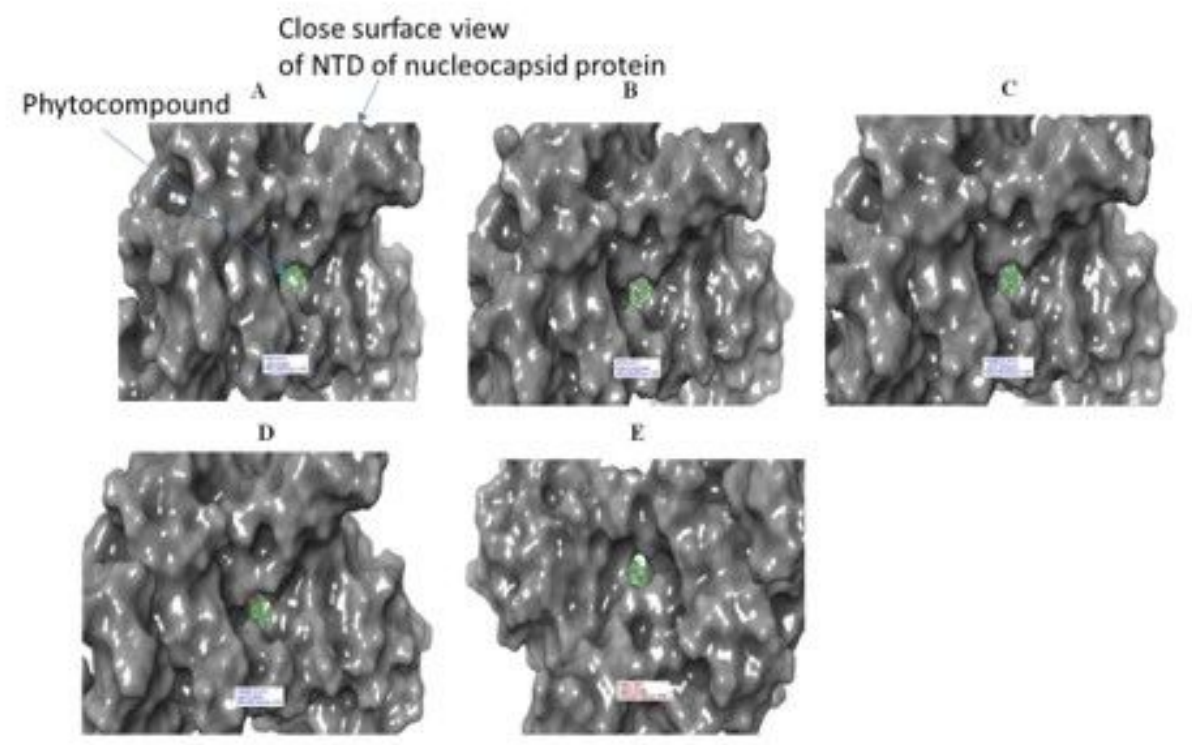

Figure 6 
Surface view of $6 \mathrm{VYO}$ (active site A) complex with best 5 compounds of selected medicinal plants: $(A)$ Alizarin, (B) Aloe- emodin, (C) Anthrarufin (D), Dantron, (E) Emodin. Phytocompounds is colored in green.
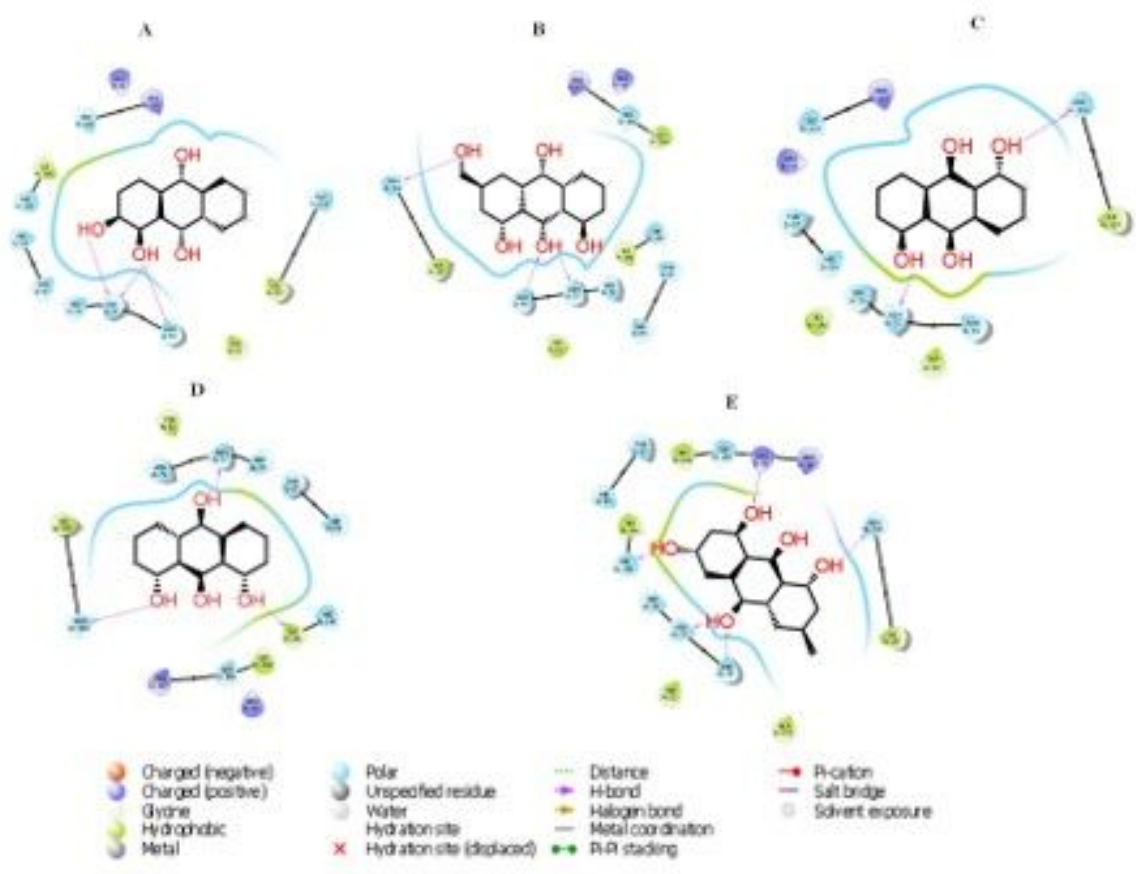

Figure 7

The 2D molecular interactions of best 5 phytocompounds with active site B of 6VYO: (A) Alizarin, (B) Aloe- emodin, (C) Anthrarufin (D) Dantron (E) Emodin

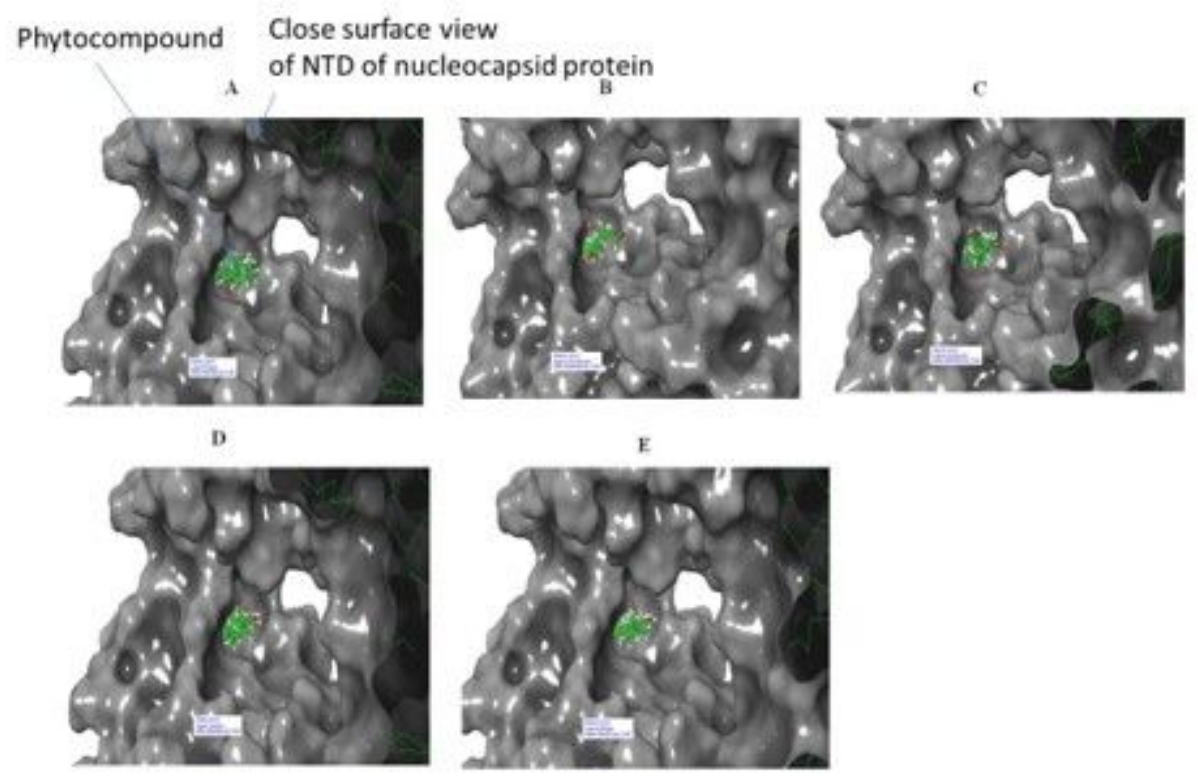

Figure 8 
Surface of $6 \mathrm{VYO}$ (active site B) with best 5 compounds: (A) Alizarin, (B) Aloe- emodin, (C) Anthrarufin (D) Dantron (E) Emodi. Phytocompounds is colored in green.
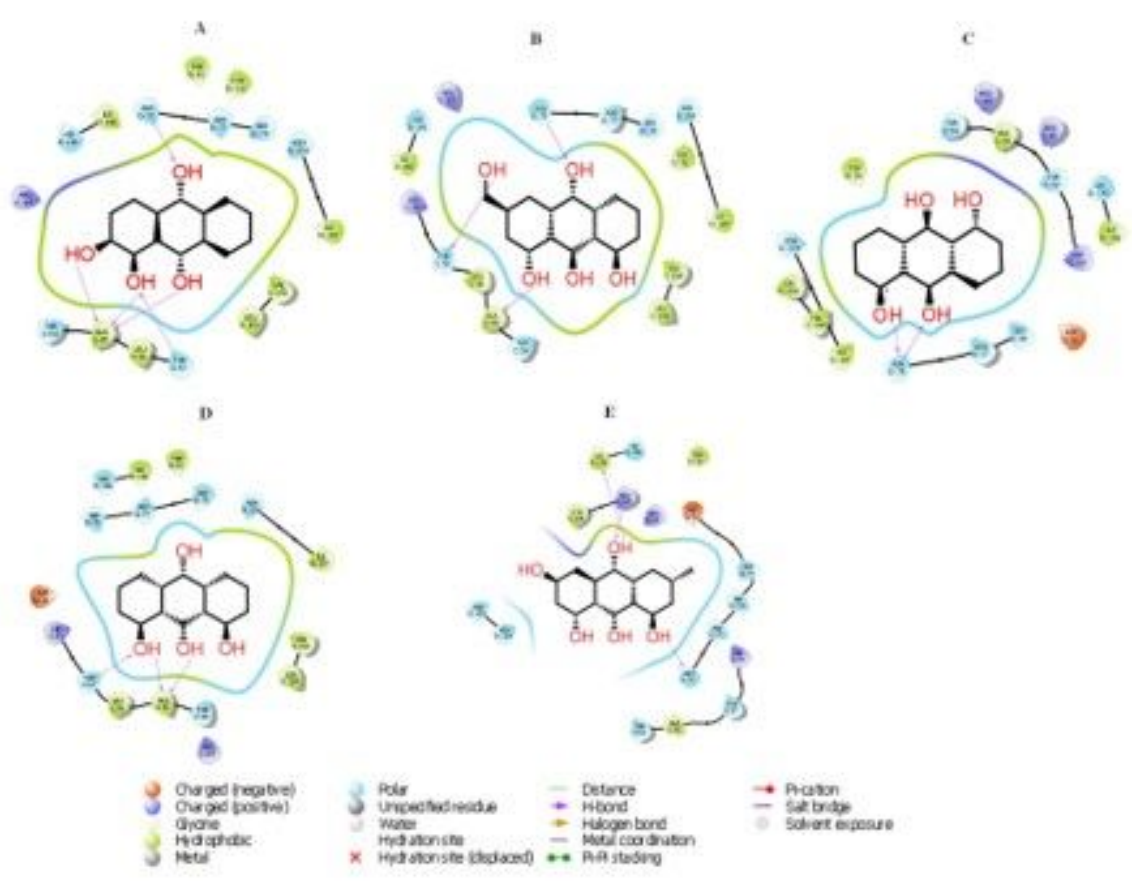

\section{Figure 9}

The 2D molecular interactions of best 5 phytocompounds with active site $\mathrm{C}$ of 6VYO: (A) Alizarin, (B) Aloe- emodin, (C) Anthrarufin (D) Dantron (E) Emodin. Phytocompounds is colored in green.

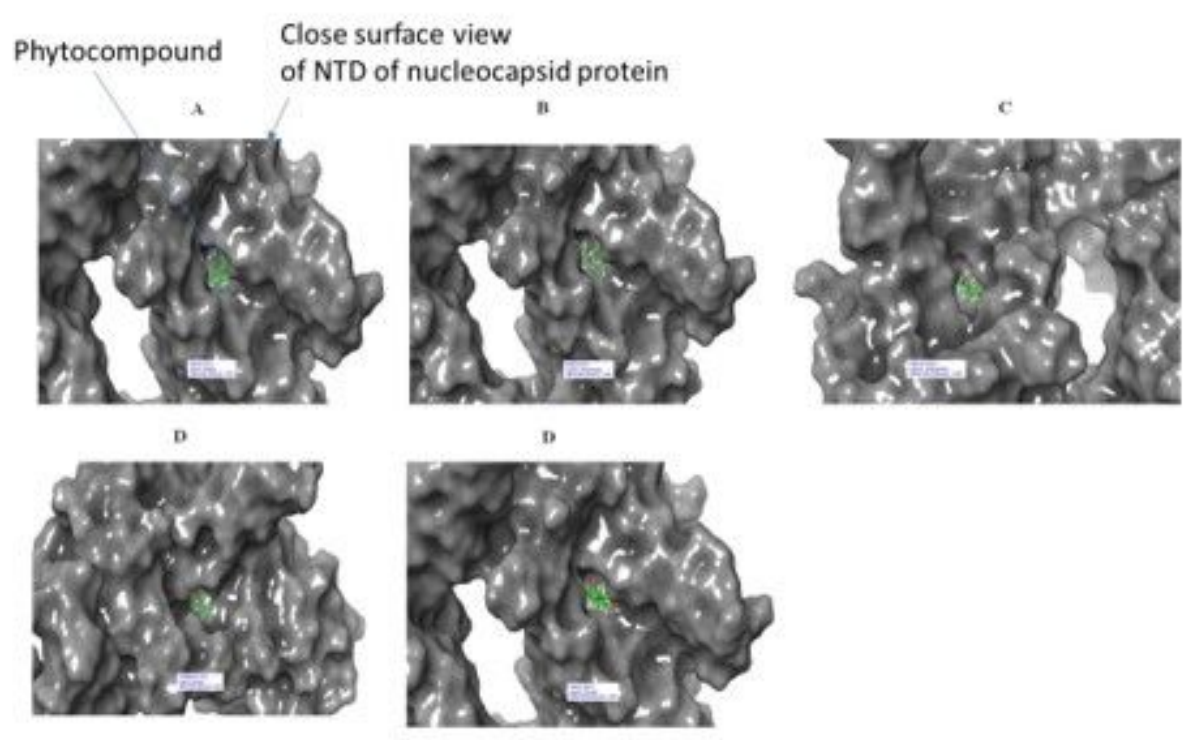

Figure 10 
Surface of 6VYO (active site C) and 5 best compounds complex: (A) Alizarin, (B) Aloe- emodin, (C) Anthrarufin (D) Dantron (E) Emodin. Phytocompounds is colored in green.

\section{Supplementary Files}

This is a list of supplementary files associated with this preprint. Click to download.

- RoltaetalGraphicalabstract.docx 